\title{
Mid-early late Albian foraminiferal assemblage from the El Abra Formation in the El Madroño locality, eastern Valles-San Luis Potosí Platform, Mexico: Paleoenvironmental and paleobiogeographical significance
}

\author{
Lourdes Omaña, Gloria Alencaster, Blanca Estela Buitrón
}

\begin{abstract}
Lourdes Omaña
lomanya@geologia.unam.mx

Departamento de Paleontología, Instituto de Geología, Universidad Nacional Autónoma de México, Ciudad Universitaria, 04510, GDMX, México.
\end{abstract}

\section{Gloria Alencaster}

Departamento de Paleontología, Instituto de Geología, Universidad Nacional Autónoma de México, Ciudad Universitaria, 04510, CDMX, México.

\section{Blanca Estela Buitrón}

Departamento de Paleontología, Instituto de Geología, Universidad Nacional Autónoma de México, Ciudad Universitaria, 04510, CDMX, México.

BOL. SOC. GEOL. MEX. 2016

VOL. 68 NO. 3

P. $477-496$

Manuscript received: January 13, 2016 Corrected manuscript: April 1, 2016 Manuscript accepted: April 8, 2016

\begin{abstract}
Albian-Cenomanian carbonate deposits of the El Abra Formation are widely distributed in the folded Sierra Madre Oriental. At the El Madroño locality, this stratigraphic unit contains an abundant, diverse and well-preserved fossil association composed of foraminifers and algae as well as rudists and other kinds of bivalves, gastropods, as well as corals, echinoids, and sponges. The El Madroño site is located in the NE extreme of the state of Querétaro in central-eastern Mexico. The foraminiferal assemblage is well-preserved and consists mostly of orbitolinids: Dictyoconus walnutensis (Carsey, 1926), $\mathrm{P} a$ racoskinolina sunnilandensis (Maync, 1955b), Coskinolinoides texanus (Keijzer, 1942), as well as Buccicrenata subgoodlandensis (Vanderpool, 1933), Novalesia angulosa (Magniez, 1972), Mayncina sp., Istriloculina sp., Arenobulimina sp., Buccicrenata sp. and $r$ strategist planktic foraminifers such as Favusella washitensis (Carsey, 1926), Muricohedbergella simplex (Morrow, 1934), and $M$. albiana (BouDagher-Fadel, et al., 1996).

Among the calcareous algae are Cayeuxia kurdistanensis Elliott, 1957, Terquemella americana (Konishi and Epis, 1962), Acroporella sp., Triploporella sp., and the encruster $\mathrm{Li}^{-}$ thocodium aggregatum Elliott, 1956.

The age assignment of the deposit is based on the benthic foraminifer Dictyoconus walnutensis, which is considered a regional marker of middle Albian age, however this succession spans to the early Albian. The paleoenvironmental reconstruction, inferred from the lithology and benthic assemblage, suggests a warm shallow-water platform.
\end{abstract}

Keywords: Albian, foraminiferal assemblage, El Madroño, VallesSan Luis Potosí Platform, Mexico.

\section{RESUMEN}

Los depósitos carbonatados del Albiano-Cenoma niano de la Formación El Abra están ampliamen te distribuidos en la Sierra Madre Oriental. En la localidad de El Madroño, èsta unidad estratigráfica cuenta con una abundante, diversa y bien preservada asociación compuesta de foraminíferos y algas así como rudistas y otros bivalvos, gasterópodos, así como corales, echinoides y esponjas. El Madroño esta localizado en el extremo NE del estado de Querétaro, en el centro-este de México. La asociación de foraminiferos está bien preservada; principalmente consiste de orbitolinídos:

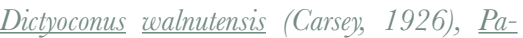
racoskinolina sunnilandensis (Maync, 1955 b), Coskinolinoides texanus (Keijzer, 1942), Buccicrenata subgoodlandensis (Vanderpool, 1933), Novalesia angulosa (Magniez, 1972), Mavncina sp., Istriloculina sp., Arenobulimina sp., Buccicrenata sp. y los foraminiferos planctónicos con estrategia r como Favusella washitensis (Carsey, 1926), Muricohedbergella simplex (Morrow,

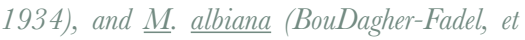
al., 1996).

Entre las algas calcáreas están Cayeuxia kurdistanensis Elliott, 1957, Terquemella americana (Konishi and Epis, 1962), Acroporella sp., Triploporella sp, y el incrustante Lithocodium aggregatum Elliott, 1956.

La edad asignada al depósito está basada en el foraminifero bentónico Dictyoconus walnutensis el cual es considerado un marcador regional para la edad Albiano medio, sin embargo esta sucesión se extiende al Albiano temprano. La reconstrucción paleoambiental es inferida de la litología y la asociación bentónica que sugieren un ambiente de plataforma de aguas cálidas someras.

Palabras clave: Albiano, asociación de foraminíferos, El Madroño, Plataforma Valles-San Luis Potosí, México. 


\section{Introduction}

In the mid-Cretaceous, shallow-water platforms were widely distributed surrounding the Gulf of Mexico basin, particularly during the Albian, where carbonate deposition extended from the Bahamas along the northern rim of the Gulf, across Mexico to the Yucatan Peninsula, and to various Caribbean localities (Scott, 1990). The larger benthic foraminifers that inhabited such environments are an important tool for dating these rocks (Schroeder and Neumann, 1985). In this paper these microfossils are also used for age assignment. Garfias (1915) was the first to use the term El Abra Limestone for the shallow-water carbonates from the Sierra de El Abra. The El Abra Formation is a carbonate complex widely distributed in the Valles-San Luis Potosí Platform (VSLPP), cropping out in the central part of San Luis Potosí State and some areas of the states of Guanajuato, Querétaro, Hidalgo, Tamaulipas and Nuevo León (Carrillo-Bravo, 1971; Wilson and Ward, 1993). This unit comprises two different facies or members based on the lithology and faunal characteristics, which were recognized in the earliest studies. The Taninul facies consists of massive and very thick limestone ranging from light to medium gray color, containing a great variety of invertebrates, mostly rudists, other bivalves, gastropods, echinoids, foraminifers and algae. The El Abra facies, which is cream in color and contains numerous miliolids, is a lagoonal facies from the Albian-Cenomanian (Aguayo, 1998).

The stratigraphic framework for the Valles-San Luis Potosí platform has been reported by Nigra (1950), Carrillo Bravo (1971), Smith (1986), Basañez et al. (1993), Wilson and Ward (1993). The sedimentology of the El Abra process has been documented by Minero (1982), Enos et al. (1983), Enos and Stephens (1993) and Aguayo (1998).

Paleontological studies of the taxonomy of rudists from the El Madroño locality have been published by Alencaster (1987, 1998), Scott (1990), and Alencáster and García Barrera (2008); based on the study of these fossils, the authors have assigned an age from the late Albian to early Cenomanian. Albian-Cenomanian benthic foraminifera from the El Abra Formation located in the eastern part of the VSLPP were reported by Bonet (1952, 1956), Tavitas and Solano (1984), Ornelas et al. (2006). Rosales-Domínguez (1998) made the first taxonomic study of the foraminifers from the El Madroño locality (state of Querétaro). Buitrón et al. (1995) analyzed Albian gastropods, foraminifera and algae from the Ahuacatlán region also in the state of Querétaro. The El Abra Formation has generally been assigned to the Albian and Cenomanian (Muir, 1936), based mostly on the invertebrate fossils. Later paleontological studies from the top of the El Abra Formation specify an early Cenomanian chronostratigraphic position (Young, 1977, 1984). Recent studies based on the benthic foraminifers indicate that in the west part of the VSLPP the age assigned to the El Abra Formation spans to the mid-late Cenomanian (Omaña et al., 2013).

The objective of this paper is to document the occurrence of the benthic foraminifera and algae from the El Abra limestone samples collected from El Madroño in order to date this interval. The microfacies were analyzed with the aim of inferring the paleoenvironmental conditions; the paleobiogeographic distribution of the foraminifers was also examined.

\section{Geological Setting}

The study area is located near the town of $\mathrm{El}$ Madroño situated in the NE part of the state of Querétaro (Figure 1). This area lies on the southeastern edge of the VSLPP.

The VSLPP is part of an extensive carbonate platform system that rimmed the ancestral Gulf of Mexico during the mid-Cretaceous. The Early Cretaceous was a time of remarkable tectonic stability in the Gulf of Mexico basin, characterized by a decrease in terrigenous influx and development of stable shelves, ramps and platforms bordering the deep central part of the Gulf of Mexico 
basin, which became the site of widespread carbonate deposition, particularly during the Albian (Salvador, 1991).

According to Wilson and Ward (1993) the VSLPP is one of "the largest isolated carbonate platforms
(200 by $300 \mathrm{~km}$.) located on the western side of the Gulf of Mexico, it began to develop in Early Cretaceous but reached maximum growth during the Albian when it evolved a rimmed shelf margin. The platform apparently formed along the
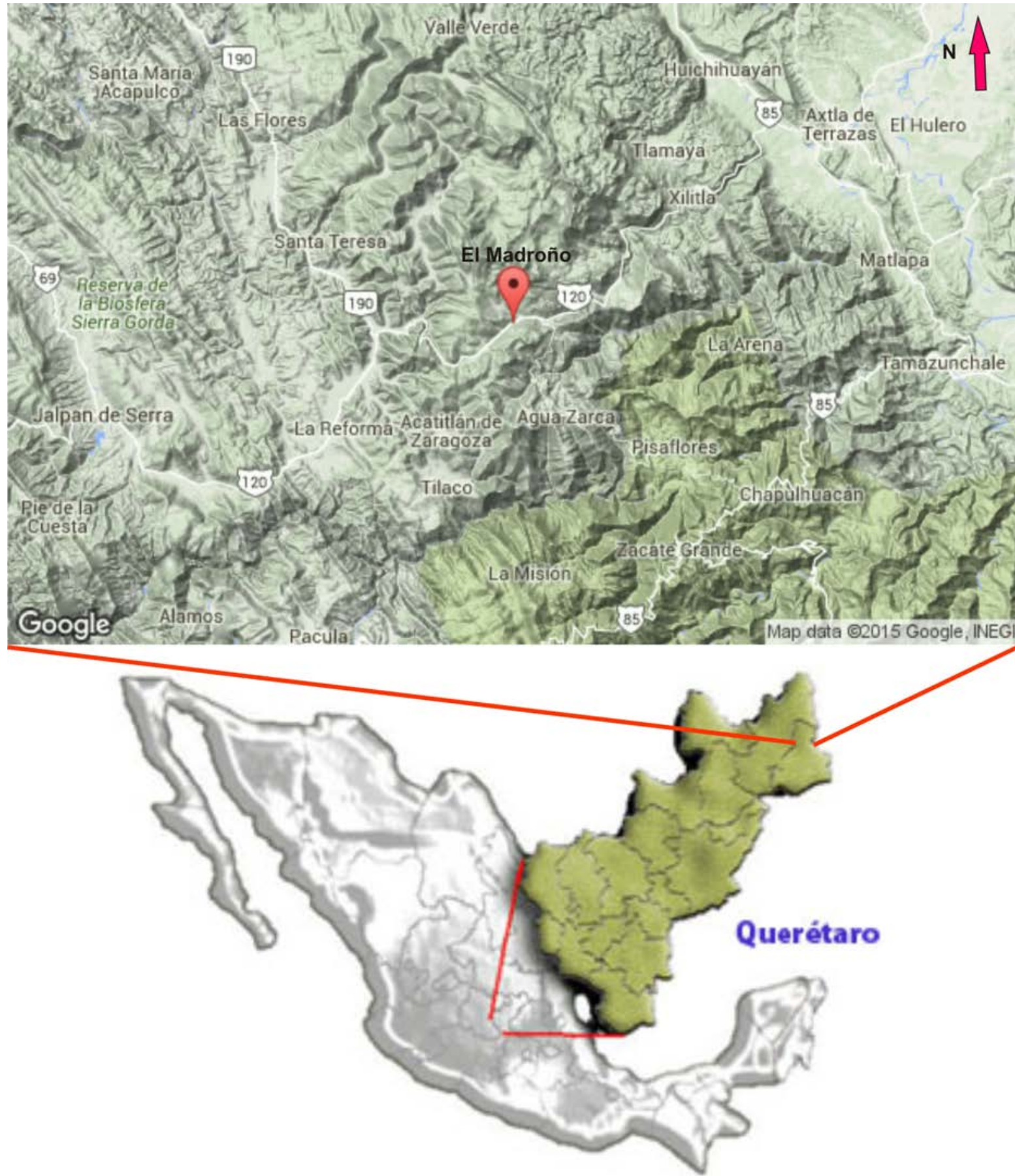
southwestern flank of a north-northwest-trending tectonic ridge of Precambrian gneiss and Upper Paleozoic schist which is exposed at Miquihuana, $70 \mathrm{~km}$. southwest of Ciudad Victoria on the state line of Nuevo León and Tamaulipas. Here thin Lower Cretaceous rocks rest unconformably on Jurassic red-beds, which lie unconformably on Upper Paleozoic talcose sericitic schists"

Carrillo-Bravo (1971) describes to the VSLPP as a "Barremian-Aptian rudist reef-rimmed, almost atoll-like configuration". This carbonate platform is believed to have surrounded a lagoon filled with evaporites and terrigenous mud of the 2000 m-thick Guaxcamá Formation. The Lower Cretaceous rocks are overlain by $1500-2000 \mathrm{~m}$ of Albian-Cenomanian reef and backreef carbonate rocks termed the El Abra Formation (Garfias, 1915, Carrillo-Bravo, 1971).

The Albian-Cenomanian carbonate platform now lies within the Sierra Madre Oriental fold thrust belt (Suter 1984, 1987, 1990). Its eastern shelf margin is exposed in quarries along the Cuesta de El Abra near Valles and Antiguo Morelos. Part of its western side is seen along road cuts $30 \mathrm{~km}$ east of the city of San Luis Potosí.

\section{Material and Methods}

The samples come from the Taninul facies collected of the El Madroño site, which is located approximately $50 \mathrm{~km}$ from Jalpan (Querétaro) in the direction of Xilitla (San Luis Potosí) at km 233 on Federal Highway 120. The outcrops form low hills covered by red soil that are visible on both sides of the highway.

We measured a section $(65 \mathrm{~m})$ and collected 12 limestone samples at an average interval of 4 to $5 \mathrm{~m}$ (Figure 2). The top of the section is capped by red soil. For micropaleontological and microfacies analysis, the samples were prepared in thin sections $50 \mu \mathrm{m}$ thick. The faunal preservation is good, which permitted a precise identification of foraminifers and algae for age assignment. In addition, a microfacies study was carried out for re- constructing the paleoenvironment.

\section{Results and Discussion}

\subsection{FORAMINIFERAL ASSEMBLAGE AND AGE}

The foraminiferal assemblage is composed mostly of the orbitolinids Dictyoconus walnutensis (Carsey, 1926), Paracoskinolina sunnilandensis (Maync, 1955b), Coskinolinoides texanus (Keijzer, 1942), which are helpful for having a short stratigraphic range. Other foraminifers identified were Buccicrenata subgoodlandensis (Vanderpool, 1933), Novalesia angulosa (Magniez, 1972), Mayncina sp., Istriloculina sp., Arenobulimina sp., Buccicrenata sp. and the planktics Favusella washitensis (Carsey, 1926), Muricohedbergella simplex (Morrow, 1934), and M. albiana (BouDagher-Fadel et al., 1996) (Figures 3-5).

The algae are Cayeuxia kurdistanensis Elliott, 1957, Terquemella americana (Konishi and Epis, 1962), Triploporella sp., Acroporella sp. and the encruster Lithocodium aggregatum Elliot, 1956 (Figure 6).

The benthic foraminifera provide a useful tool for age assignment using the stratigraphic ranges of the age diagnostic species.

The most important foraminifers used for dating the El Madroño succession are the orbitolinids Dictyoconus walnutensis (Carsey, 1926), Coskinolinoides texanus (Keijzer, 1942), Paracoskinolina sunnilandensis (Maync, 1955b), which support a mid-early late Albian age considering that the studied succession precedes the global sea-level rise that took place in the late Albian (Grötsch et al., 1993; Filkorn and Scott, 2011). The occurrence of other species such as Buccicrenata subgoodlandensis (Vanderpool, 1933), Novalesia angulosa (Magniez, 1972); Istriloculina sp., Buccicrenata sp., Arenobulimina sp. and the $r$ strategist planktics Favusella washitensis (Carsey, 1926), Muricohedbergella albiana (BouDagher-Fadel et al., 1996) and Muricohedbergella simplex (Morrow, 1934) is in accord with the determined age.

Dictyoconus walnutensis (Figure 3a-c) was described by Carsey (1926) as Orbitolina from the Walnut Clay of the Cretaceous of central Texas; Silvestri 

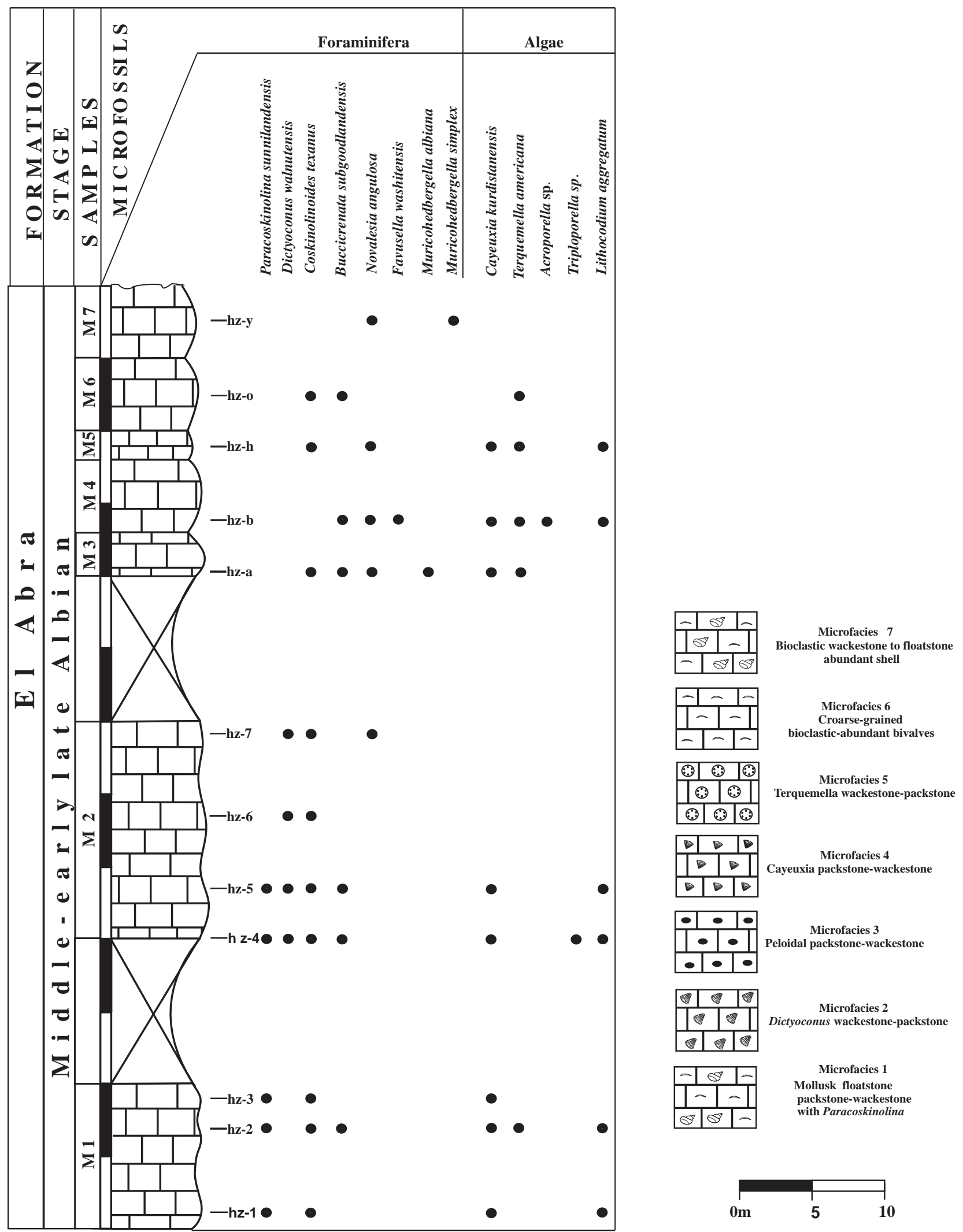

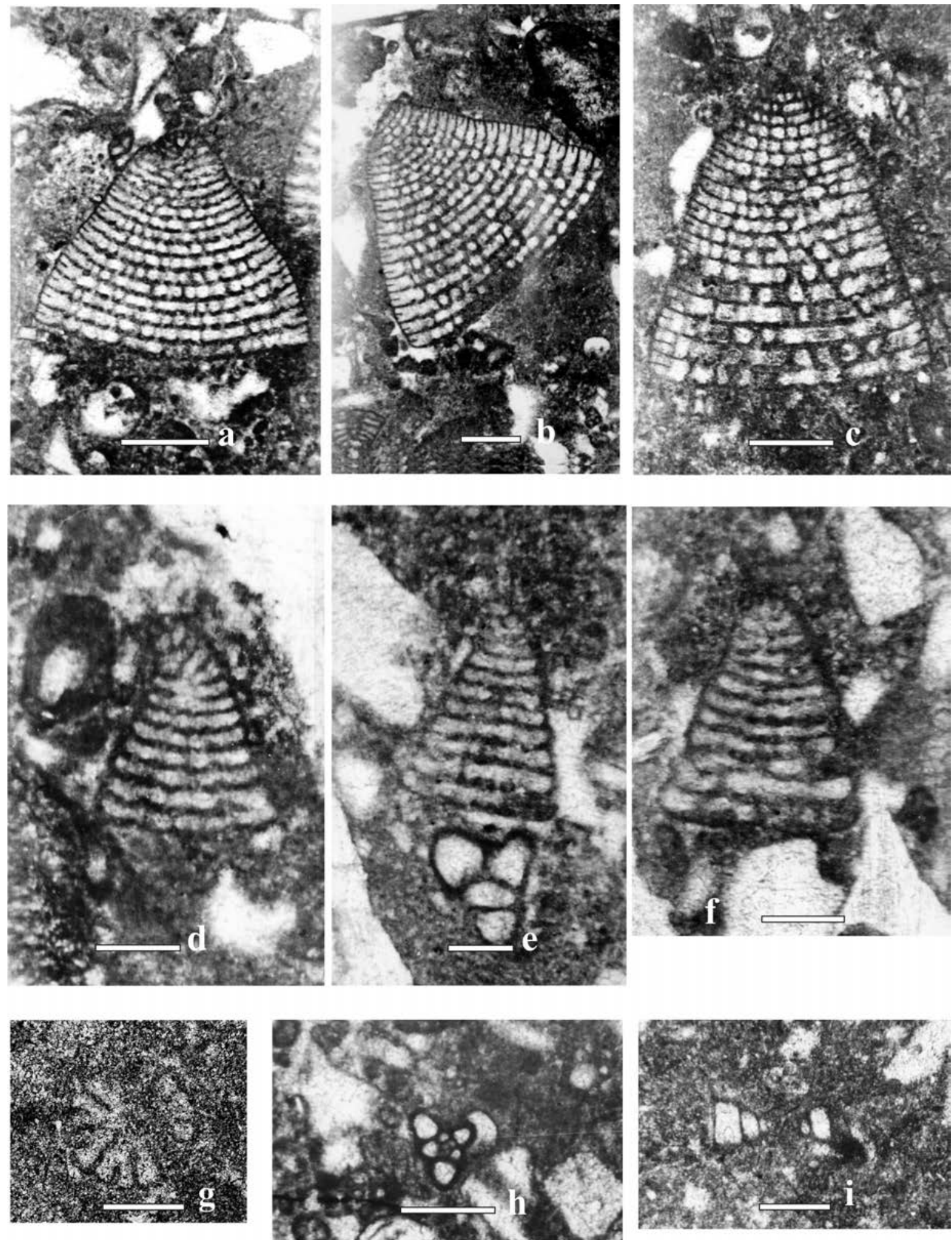

Figure 3 Mid-early late Albian foraminifera from the El Abra Formation. a- Axial section of Dictyoconus walnutensis (Carsey, 1926) hz-4 (scale bar $500 \mu \mathrm{m}$ ). b- Subaxial section Dictyoconus walnutensis (Carsey, 1926) hz-4 (scale bar $500 \mu \mathrm{m}$ ). c- Subaxial section Dictyoconus walnutensis (Carsey, 1926) hz-5 (scale bar $500 \mu \mathrm{m}$ ). d, e, f- Axial and transverse section of Coskinolinoides texanus (Keijzer, 1942) hz-5 (scale bar $200 \mu \mathrm{m}$ ). g- Horizontal section of Coskinolinoides texanus (Keijzer, 1942) hz-2 (scale bar $300 \mu \mathrm{m}) \mathrm{h}-$ Miliolid hz-5 (scale bar $300 \mu \mathrm{m}$ ). i- Axial section Spiroloculina hz-5 (scale bar $300 \mu \mathrm{m}$ ). 
(1932, p. 377 in Douglass, 1960) subsequently reassigned it to the genus Dictyoconus. Barker (1944, p. 206) found this species only in the Comanche Peak of the Austin region, it also was recorded from the Fredericksburg (Scott, 1990; Scott et al., 2003 in Texas. In addition this species has been identified in the subsurface of Florida (Applin and Applin, 1965). Maync (1955a) recorded the species in the Lower Cretaceous (Guácharo limestone) of eastern Venezuela and prepared a detailed description. Dictyoconus walnutensis is widespread in the Gulf of Mexico region and has been regarded as a stratigraphic marker restricted to the mid-Albian (Douglass, 1960; Maync, 1955a; Bonet, 1956; Scott, 1990; Scott and González-León, 1991; Buitrón et al., 1995; Omaña and Alencaster, 2001; Monreal and Longoria, 1999; Fourcade $e t$ al., 1999; Waite et al., 2007); however, it could have ranged to the early late Albian (Phelps et al., 2015). In North Texas this species ranges to the top of Goodland Formation in which the basal upper Albian ammonite Dipoloceras cristatum occurs; so $D$. walnutensis ranges into basal upper Albian (written communication Scott, 2016).

In Mexico, Dictyoconus walnutensis (Carsey, 1926) is broadly distributed. It has been reported from the following formations: Finlay (Monreal and Longoria, 1999); Espinazo del Diablo (Scott and González-León, 1991); El Abra (Bonet, 1956, Buitrón et al., 1995; Rosales-Domínguez, 1998; Omaña and Alencáster, 2001); Escamela (Bonet, 1956), and Morelos (Flores de Dios et al., 2004) in the states of Chihuahua, Sonora, Querétaro, Veracruz and Guerrero respectively.

Paracoskinolina sunnilandensis (Figure 4a-g) has been described from the Lower Cretaceous (Albian) Sunniland limestone of Florida, as Coskinolina by Maync (1955b), and later transferred to the genus Paracoskinolina by Moullade (1965). Maync (1955b) indicated that he observed this foraminifer from the Dictyoconus-bearing rock of Guácharo, a member of the Chimama Formation in eastern Venezuela which was dated as middle Albian (Rod and Maync, 1954). Scott and González-León (2004) identified P. sunnilandensis (Maync, 1955b) from the
Mural Limestone (Sonora); in Chiapas it has been recorded as Albian from the Sierra Madre Formation (Michaud, 1987). Arnaud-Vanneau and Sliter (1995 p. 544) also found the species at Site 866 on Resolution Guyot in the Pacific Ocean. According to Maync (1955b, p. 106) the species is known from Switzerland. In France the stratigraphic distribution of Paracoskinolina cf. P. sunnilandensis is early Barremian from the Hugii and Nicklesi Zones (Clavel et al., 2010).

Coskinolinoides texanus (Figure $3 \mathrm{~d}-\mathrm{f}$ ) was originally described from the Walnut clay, of Lower Cretaceous (Fredericksburg) west of Austin, Texas by Keijzer in 1942, associated with Dictyoconus walnutensis (Carsey, 1926) is considered to characterize the Comanche Peak in central Texas (Lozo, 1944, p. 570). Applin and Applin (1965) indicated that in Florida "the species seems to be limited in its vertical range to the beds of Fredericksburg age, and specimens generally occur in greatest abundance in the upper part of the unit. Frizzell (1954, p. 76), reported that in Texas, C. texanus ranges upward from the Glen Rose Limestone of the Trinity Group into the progressively younger Walnut Clay, Comanche Peak Limestone, and Goodland Limestone of the Fredericksburg Group". Phelps et al. (2015) indicated that this species ranges from the mid-to-upper Albian from west Texas. In Mexico, C. texanus has been reported by Scott and González-León (1991), Rosales-Domínguez (1998), Omaña and Alencaster (2001), Flores de Dios et al. (2004); and in the Dominican Republic the occurrence of $C$. texanus suggests that the Hatillo Limestone spans to the middle Albian (Bonilla-Rodríguez, 2013).

We identified other foraminifers such as Ammobaculites subgoodlandensis (Figure 5a), which was defined by Vanderpool (1933) from the mid-Albian Comanchean "formation" in southern Oklahoma, later placed in the genus Buccicrenata by Loeblich and Tappan (1949).

Filkorn and Scott (2011) found Buccicrenata subgoodlandensis (Vanderpool, 1933) in the Mal Paso Formation in Guerrero state (Mexico) with a foraminiferal association dated as late Albian; they 

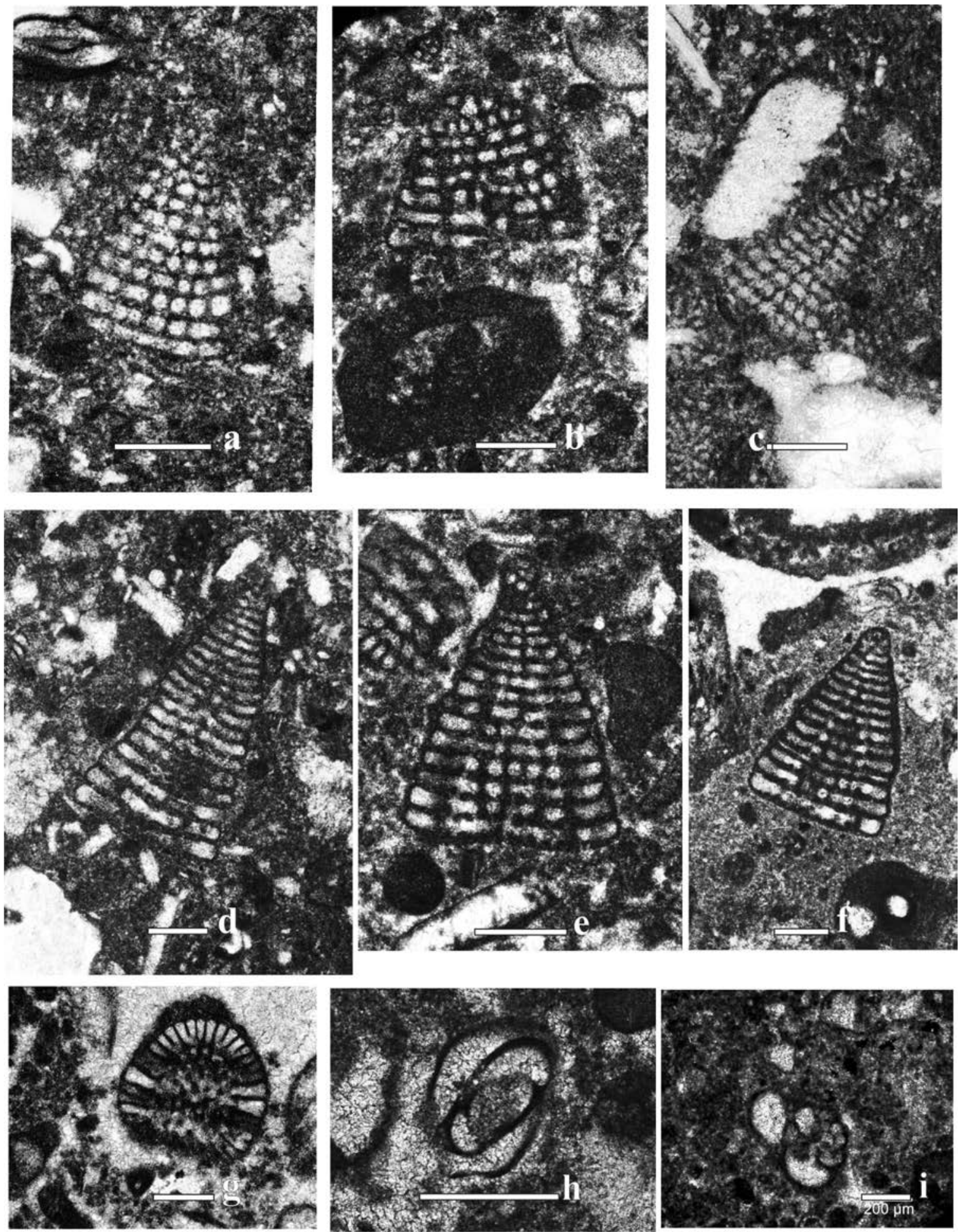

Figure 4 Mid-early late Albian foraminifera from the El Abra Formation. a- Subaxial section Paracoskinolina sunnilandensis (Maync, 1955b) hz-3 (scale bar $300 \mu \mathrm{m}$ ). b- Subaxial section of Paracoskinolina sunnilandensis (Maync, 1955b) hz-2 (scale bar $300 \mu \mathrm{m}$ ). cSubaxial section of Paracoskinolina sunnilandensis (Maync, 1955b) hz-3 (scale bar $300 \mu \mathrm{m}$ ). d- Subaxial section of Paracoskinolina. sunnilandensis (Maync, 1955b) hz-3 (scale bar 500 нm). e- Axial section of Paracoskinolina sunnilandensis (Maync, 1955b) hz-1 (scale bar $500 \mu \mathrm{m}$ ). f- Axial section of Paracoskinolina sunnilandensis (Maync, 1955b) hz-2 (scale bar $500 \mu \mathrm{m}$ ). g- Transverse section of Paracoskinolina sunnilandensis (Maync, 1955b) (scale bar $500 \mu \mathrm{m}$ ). h- Istriloculina sp. Sample hz-2 (scale bar $200 \mu \mathrm{m}$ ). i- Arenobulimina sp. Sample hz-b (scale bar $200 \mu \mathrm{m}$ ). 
indicated that the stratigraphic range of this species extends throughout the Albian in Tethyan sections from North America and the Middle East. In Texas, it occurs in the lower Albian Glen Rose Formation and the lower to upper Albian Walnut and Goodland formations of the Fredericksburg Group. These authors note that B. subgoodlandensis has been reported as $P$. hedbergi from mid-upper Albian strata in Mexico (Scott and González-León, 1991) and Honduras (Scott and Finch, 1999). In Florida it was identified as Lituola subgoodlandensis, which is associated with Coskinolinoides texanus (Keijzer) in the Fredericksburg Group (Applin and Applin, 1965). This species was recognized from the lower-upper Albian Nahr Umr Formation in the Arab Emirates and Oman (Banner and Highton, 1990; BouDagher-Fadel, 2001). In our material it is associated with mid-Albian-early late Albian microfauna.

Novalesia angulosa (Figure 5d, e) was described from the Albian of the Spanish Pyrenees as Spiroplectamminoides by Magniez 1972, and later assigned to Novalesia (Magniez, 1974). The known range is late Aptian to Albian (Arnaud-Vanneau and Sliter, 1995). This species is common in the El Madroño samples.

We identified a specimen of Favusella washitensis (Figure 5g), which was reported by Carsey (1926) as Globigerina washitensis from the Del Rio Formation of Texas, USA, and later placed in the subgenus Favusella by Michael (1972). The stratigraphic range of the species spans from the Albian to early Cenomanian (Premoli-Silva and Sliter, 2002).

Muricohedbergella albiana (BouDagher-Fadel et al., 1996) (Figure 5i) extends from the latest early Albian to late Albian Ticinella primula Zone to the Rotalipora appenninica Zone (Premoli -Silva and Verga, 2004; Huber, 2006); however, it has been also reported by Magniez-Jannin (1975) from mid-Albian of the Aube, France.

We also recognized Muricohedbergella simplex (Morrow, 1934) (Figure 5h), which ranges from the upper part of the Ticinella primula Zone in the mid-Albian to Coniacian (Premoli-Silva and Verga, 2004). Although these planktic foraminife- ra identified have a wide stratigraphic distribution they are in the interval of the assigned age.

\subsection{PALEOECOLOGY}

The Recent larger foraminifera are distributed in tropical and subtropical regions and they are most abundant in nutrient-deficient, warm, shallow-water seas (Boudagher-Fadel, 2008). Murray (2006) stated that "the controls on global distribution are thought to be water temperature, nutrient content, light intensity and hydrodynamic energy." The light required by their symbionts led to the establishment of the depth distribution of the larger foraminiferal assemblage as a water-depth proxy indicating a shallow-water setting.

The ecology of larger foraminifera without equivalent recent forms could be inferred from the size, morphostructure, and test architecture. The dictyoconids such as Dictyoconus, Paracoskinolina, and Coskinolinoides are characterized by having a conical test which suggests a free, epifaunal mode of life on soft substrates. This is confirmed by the wackestone textured rock where they were deposited, which permitted the inference that it occurred in a warm shallow-water platform with low energy in the euphotic zone, because they are associated with algae.

\subsection{MICROFACIES AND PALEOENVIRONMENT}

The paleoenvironmental interpretation is based on the foraminiferal-algae association and the microfacies study.

The thin section analysis of the textural features and faunal assemblage of the limestone enabled us to recognise several microfacies. They are described below from the base towards the top of the section. The succession is characterized by the occurrence of larger foraminifers such as orbitolinids, other small benthic formainifers as Novalesia sp., Istriloculina sp., Arenobulimina sp. and planktic organisms, as well as fragments of rudists, gastropods, echinoid, and algae and encrusters.

Microfacies 1 (Sample hz-1-3) Mollusk floatstone and foraminiferal packstone-wackestone is cha- 

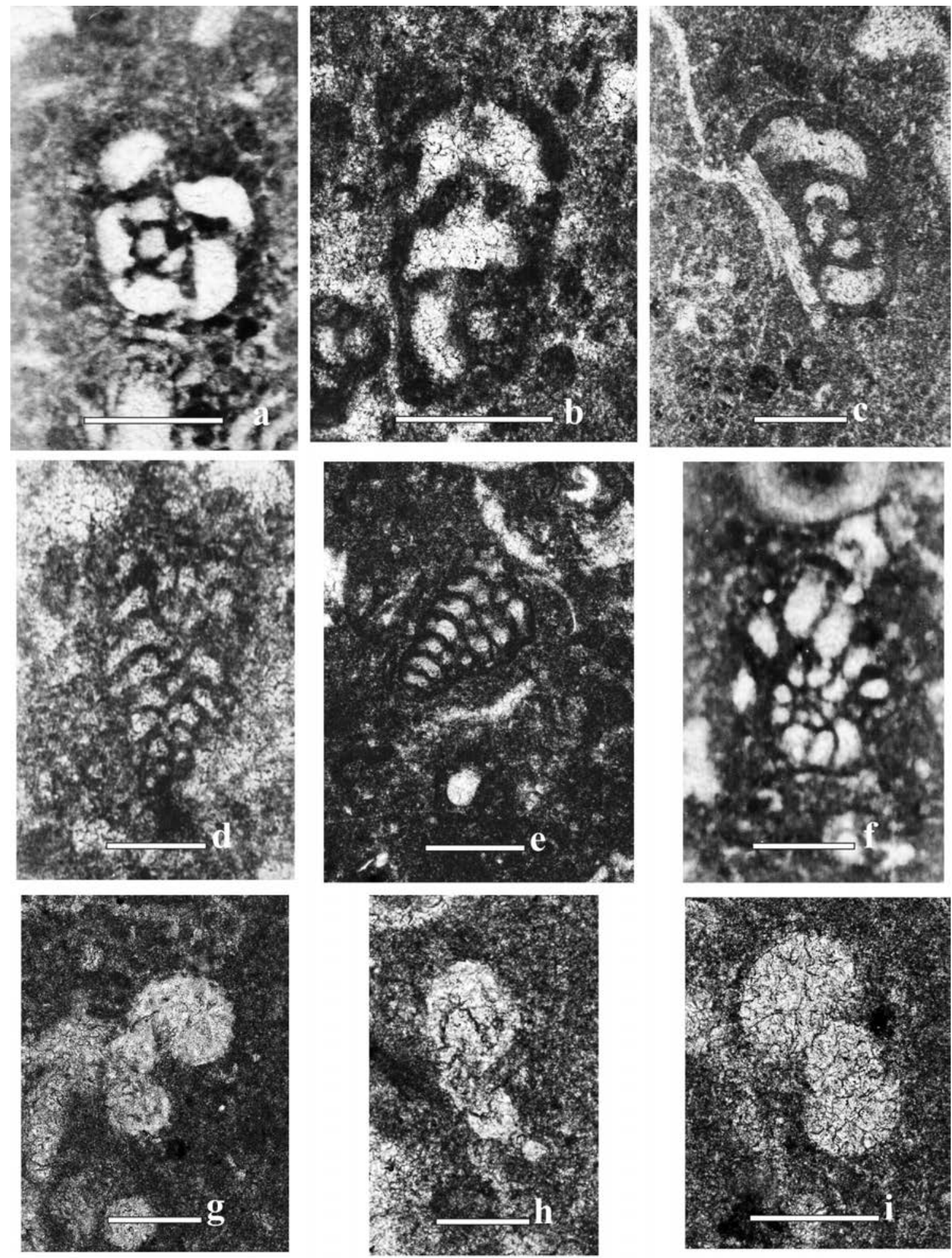

Figure 5 Mid-early late Albian foraminifera from the El Abra Formation. a- Equatorial section of Buccicrenata subgoodlandensis (Vanderpool, 1933) hz-4 (scale bar $300 \mu \mathrm{m}$ ). b- Subequatorial section of Buccicrenata sp. hz-2 (scale bar $300 \mu \mathrm{m}$ ). c- Subaxial section of Buccicrenata sp. hz-a (2) (scale bar $300 \mu \mathrm{m}$ ). d- Novalesia angulosa (Magniez, 1972) hz-a (1) (scale bar $300 \mu \mathrm{m}$ ). e- Novalesia angulosa (Magniez, 1972) hz-6 (scale bar $500 \mu \mathrm{m}$ ). f- Equatorial section of Mayncina sp. hz-6 (scale bar $300 \mu \mathrm{m}$ ). g- Axial section of Favusella washitensis (Carsey,) hzb (2) (scale bar $200 \mu \mathrm{m}$ ). h- Axial section of Muricohedbergella simplex (Morrow, 1934) hzy (2) (scale bar $100 \mu \mathrm{m}$ ). i- Subaxial section of Muricohedbergella albiana (BouDagher-Fadel et al., 1996) hza (2) (scale bar $200 \mu \mathrm{m})$. 

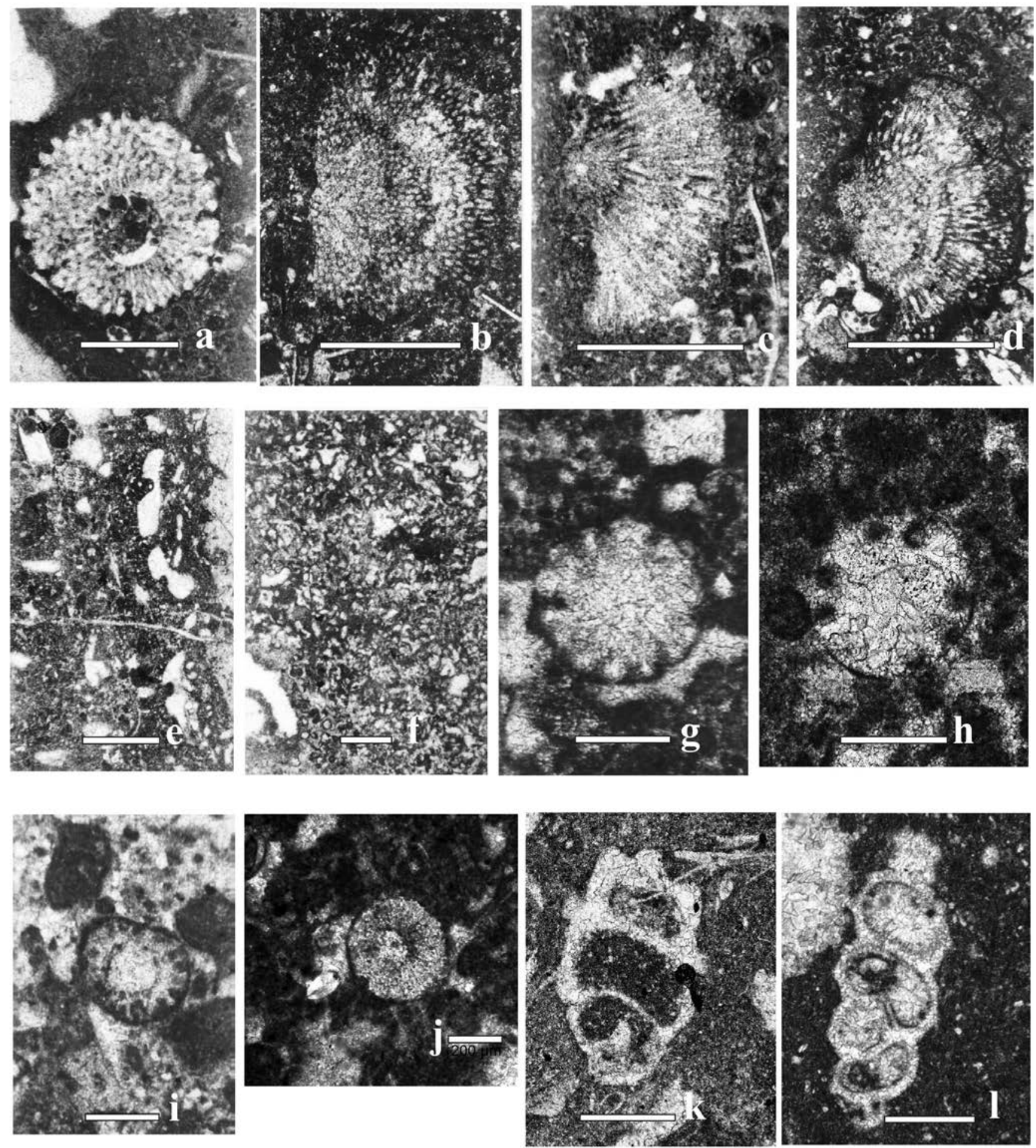

Figure 6 Mid-early late Albian algae from the El Abra Formation. a- Triploporella sp. hz-4 (scale bar 1 mm). b- Longitudinal section of Cayeuxia kurdistanensis Elliott, 1957 hza (3) (scale bar $1 \mathrm{~mm}$ ). c- Longitudinal section of Cayeuxia kurdistanensis Elliott, $1957 \mathrm{hz}-5$ (scale bar $1 \mathrm{~mm}$ ). d- Longitudinal section of Cayeuxia kurdistanensis Elliott, $1957 \mathrm{hzb}$ (a) (scale bar $1 \mathrm{~mm}$ ): e -Lithocodium aggregatum Elliott, 1956, hzb (A) (scale bar $1 \mathrm{~mm}$ ). f- Lithocodium aggregatum Elliott, 1956, hzb (A) rojo (scale bar 2 mm). g- Transverse section of Terquemella americana (Konishi and Epis, 1962) hza (2) (scale bar $300 \mu \mathrm{m}$ ). $\mathrm{h}$ - Transverse section of Terquemella americana (Konishi and Epis, 1962) hz-2 (scale bar $300 \mu \mathrm{m}$ ). i- Transverse section of Acroporella sp. hzb (3) (scale bar $300 \mu \mathrm{m})$. j- Echinoderm hzb (1) (2) (scale bar $200 \mu \mathrm{m}$ ). k- Gastropod hzo (2) (scale bar $500 \mu \mathrm{m}$ ). I- Gastropod hzh (2) (scale bar $500 \mu \mathrm{m}$ ). 
racterized by a foraminiferal association composed mostly of Paracoskinolina sunnilandensis (Maync, 1955b). Other foraminifers present are Novalesia angulosa (Magniez, 1972), Buccicrenata sp. The algae are Cayeuxia kurdistanensis Elliott, 1957; Terquemella americana (Konishi and Epis, 1962), and the encruster Lithocodium aggregatum Elliott, 1956. This interval also contains gastropods, and corals (Figure7a). Microfacies 2 (Samples hz-4-7) is a foraminiferal packstone-wackestone showing a more diversified association, contains Dictyoconus walnutensis (Carsey, 1926) and Coskinolinoides texanus (Keijzer, 1942). Also present are Paracoskinolina sunnilandensis (Maync, 1955b); Buccicrenata subgoodlandensis (Vanderpool, 1933); Novalesia angulosa (Magniez, 1972); the algae Cayeuxia kurdistanensis Elliott, 1957, Triploporella sp. and the encruster Lithocodium aggregatum Elliott, 1956 as well as gastropods and fragments of bivalves (Figure 7b,c).

Microfacies 3 (Sample hz-a) Peloidal packstone-wackestone containing benthic foraminifers Paracoskinolina sunnilandensis (Maync, 1955b), Coskinolinoides texanus Keijzer, 1942, Novalesia angulosa (Magniez, 1972), Buccicrenata sp. and algae Terquemella americana (Konishi and Epis, 1962), Cayeuxia kurdistanensis Elliott, 1957 and the planktic foraminifer Muricohedbergella albiana (BouDagher-Fadel et al., 1996) and fragments of mollusks (Figure 7d). Microfacies 4 (Sample hz-b) Algal packstone-wackestone containing Paracoskinolina, Arenobulimina sp., Cayeuxia kurdistanensis Elliott, 1957 Lithocodium aggregatum Elliott, 1956 and the planktic foraminifer $\mathrm{Fa}^{-}$ vusella washitensis (Carsey, 1926) (Figure 8a).

The depositional environment of microfacies $1-$ 4 suggests a shallow marine environment within the euphotic zone in the open marine interior platform, corresponding to Facies Zone 7 (FZ 7) (Flügel, 2004, p. 663). The fossil assemblage indicates deposition in the subtidal zone with normal salinity, stable temperature conditions and good oxygenation of the seawater.

Microfacies 5-(Sample hz-h) Shell wackestonepackstone with foraminifers Coskinolinoides texanus Keijzer, 1942, Novalesia sp. and algae Terquemella americana (Konishi and Epis, 1962), and Lithocodium aggregatum Elliott, 1956 (Figure 8b).

Microfacies 6-(Sample hz-o) Coarse-grained bioclastic-wackestone, partly floatstone, containing abundant bivalve shell fragments of mollusks, gastropods, echinoids, with scarce foraminifers, and algae (Figure 8c).

Microfacies 7-(Sample hz-y) Bioclastic wackestone to floatstone containing abundant mollusk fragments, gastropods, echinoderms, and benthic foraminifers such as Novalesia sp. and planktic $M u^{-}$ ricohedbergella simplex (Morrow, 1934) (Figure 8d).

Microfacies $5-7$ are characterized by floatstone composed of accumulations of abundant shell fragments probably caused by current concentrations, indicating deposition in an open-shelf setting with moderate energy and could correspond to Facies Zone 5 (FZ 5) of Flügel (2004).

The microfacies and the faunal association including Dictyoconinae are essentially linked to fine carbonate muddy deposits in shallow environments as has been proposed by Masse (1992) which is confirmed in the studied samples. On the other hand, the occurrence of gastropods and broken mollusk fragments in the wackestonepackstone textured limestone suggests a shallow, open-marine platform with two events, one of low energy and the other of moderate energy. The presence of algae indicates that the deposit took place within the photic zone. The existence of the $\mathrm{r}$ strategist planktic species in the association demonstrates their adaptation to a shallow-water environment, although the presence of several levels of floatstone and the scarce occurrence of these planktic foraminifers also could indicate a trend in the environment's evolution towards the platform border.

\subsection{PALEOBIOGEOGRAPHY}

Dictyoconus walnutensis (Carsey, 1926), Coskinolinoides texanus (Keijzer, 1942) and Paracoskinolina sunnilandensis (Maync, 1955b) are common species in the Gulf of Mexico area; for instance, in the USA, in Texas, New Mexico and Florida from the Fredericksburg Group, Finlay and Sunniland formations (Scott, 1990; Scott, et al., 2003; Lucas et al., 2010), 

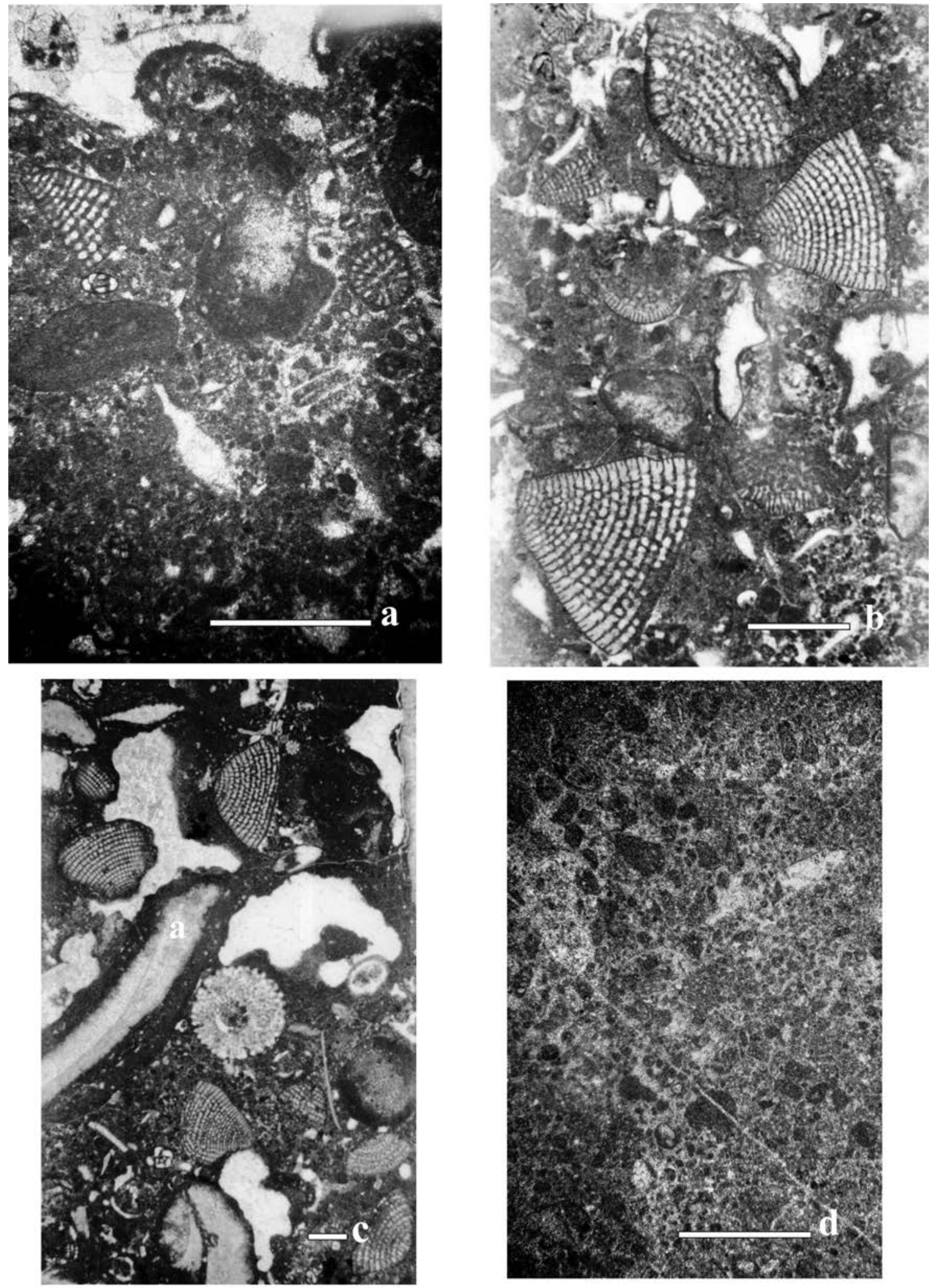

Figure 7 Microfacies from the El Abra Formation in the El Madroño locality. a- Microfacies 1 Mollusk floatstone and foraminiferal packstone-wackestone (hz-1) with Paracoskinolina sunnilandensis (scale bar $1 \mathrm{~mm}$ ). b, c Microfacies 2 (Samples Sample hz-4-7) Foraminiferal packstone-wackestone with Dictyoconus walnutensis, Coskinolinoides texanus, Buccicrenata subgoodlandensis and Triploporella sp. (scale bar $1 \mathrm{~mm}$ ). d-Microfacies 3 (Sample hz-a) Peloidal packstone-wackestone with foraminifers (scale bar $1 \mathrm{~mm}$ ). 

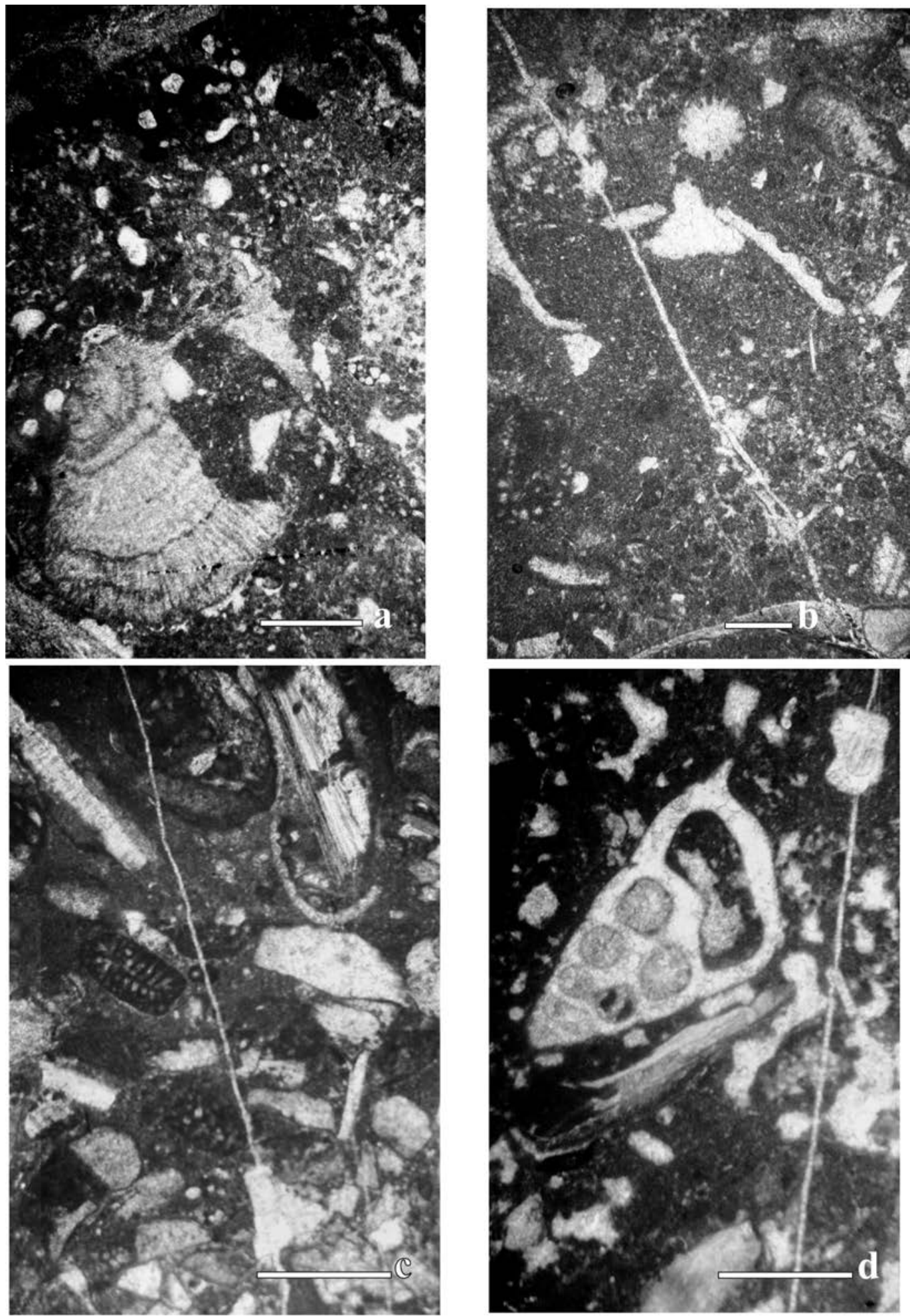

Figure 8 Microfacies from the El Abra Formation in the El Madroño locality. a- Microfacies 4 (Sample hz-b) Algal packstone-

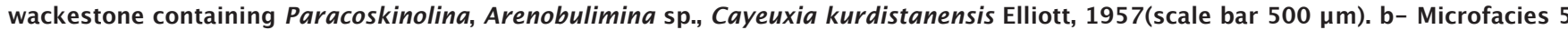
(Sample hzh) Shell wackestone-packstone with Coskinolinoides texanus, Novalesia sp. and Terquemella americana (Konishi and Epis, 1962) (scale bar $500 \mathrm{m \mu}$ ). c- Microfacies 6 (Sample Sample hz-o) Coarse-grained bioclastic wackestone, partly floatstone with scarce foraminifers (scale bar $1 \mathrm{~mm}$ ). d- Microfacies 7-(Sample $h z-y-1)$ Bioclastic wackestone to floatstone containing abundant mollusk fragments (scale bar $1 \mathrm{~mm}$ ). 
and the subsurface in the Dollar Florida Bay Formation (Bozkurt, 2015). In Mexico, this orbitolinid association is extensively distributed in the Finlay, Espinazo del Diablo, El Abra, Escamela, Morelos and the Sierra Madre formations. In addition, it is known in the Caribbean region of Guatemala in the Cobán Formation (Fourcade et al., 1999); in the Palenque Formation in Cuba (Meyerhoff and Hatten, 1974, p. 440); in Honduras in the Atima limestone (Scott and Finch, 1999); in Venezuela from the Guácharo limestone (Maync, 1955 a, b) and the Dominican Republic in the Hatillo Formation (Bonilla-Rodríguez, 2013; Bonilla et al., 2014). These species have been also identified by Granier (2005) from samples collected from the Bahamas Escarpment. Cherchi and Schroeder (1984) reported Dictyoconus walnutensis (Carsey, 1926) and Paracoskinolina sunnilandensis (Maync, 1955b) in the southwestern part of the Gulf of Mexico (Site 77) as reworked material.

According to the geographical distribution of these orbitolinids in the mid-Cretaceous (Albian) we consider that they are endemic forms for the Gulf Coast and Caribbean region into the western part of Tethys. This is in agreement with the view of Cherchi (2004) who "indicated that Dictyoconus walnutensis (Carsey, 1926) and Paracoskinolina sunnilandensis (Maync, 1955b) are restricted to the Gulf region; thus records of these taxa in the European Tethyan realm are erroneous". However Paracoskinolina $\mathrm{cf}$. P. sunnilandensis (Maync, 1955b) have been recorded in older rocks dated as early Barremian from the Urgonian platform of SE France (Clavel et al., 2010).

In addition, the other foraminifers Buccicrenata subgoodlandensis (Vanderpool, 1933), Novalesia angulosa (Magniez, 1972), Arenobulimina sp. and the planktic foraminifers have a wide distribution in the Tethys Realm.

\section{Conclusions}

The foraminiferal assemblage contained in the $\mathrm{El}$ Abra succession sampled from the El Madroño site consists of the benthic foraminifers Dictyoconus walnutensis (Carsey, 1926), Paracoskinolina sunnilandensis (Maync, 1955b45), Coskinolinoides texanus (Keijzer, 1942), Buccicrenata subgoodlandensis (Vanderpool, 1933), Novalesia angulosa (Magniez, 1972), Arenobulimina sp. and the algae species, Cayeuxia kurdistanensis Elliot, 1957, Terquemella americana (Konishi and Epis, 1962), Triploporella sp., Acroporella sp. and the encruster Lithocodium aggregatum Elliot, 1956. This assemblage is dated as mid-early late Albian based mostly on the Dictyoconus, Paracoskinolina and Coskinolinoides assemblage.

The microfacies change from wackstone-packstone to grainstone toward a floatstone indicating a shallow, open-marine environment with two phases, one of low energy and the other of moderate energy, which is inferred on the basis of the limestone texture and the benthic foraminiferal and algal association.

The foraminifers analyzed in this study are widely distributed in the shallow-water deposits of Mexico, the Gulf Coast of the United States and the Caribbean region in the western part of the Tethys Realm.

\section{Acknowledgments}

We are greatly indebted to the Instituto de Geología of the Universidad Nacional Autónoma de México for supporting this study. The stratigraphical section was measured by the late Miguel Carrillo. We gratefully acknowledge the helpful and constructive reviews of the manuscript by Dr. Robert Scott (Precision Stratigraphy Associates, USA) and Prof.ssa Antonietta Cherchi (Dipartimento di Scienze Chimiche e Geologiche, Università di Cagliari, Italy) which enabled us to improve the document.

The authors are thankful for the editorial corrections contributed by Dr. Francisco Javier Vega Vera (UNAM, Mexico), which were very helpful. We thank Barbara Martiny for revision of English and Diego and Joaquín Aparicio for preparing the thin sections. We thank José Carlos Jiménez for 
helping in the preparation of the figures.

\section{References}

Aguayo, G.E., 1998, The middle Cretaceous El Abra limestone at its type locality (facies, diagenesis and oil emplacement): Revista Mexicana de Ciencias Geológicas, 15, 1-8.

Arnaud-Vanneau, A., Sliter, W.V., 1995, Early Cretaceous shallow-water benthic foraminifers and fecal pellets from Leg 143 compared with coeval faunas from the Pacific Basin, Central America, and Tethys, in Winterer, E.L., Sager, W.W., Finch, J.V., Sinton, J.N. (eds.), Proccedings of the Ocean Drilling Program. Scientific Results 143, 537-564.

Banner, F.T., Highton, J., 1990, On Everticyclammina Redmond (Foraminifera) especially E. kelleri (Henson): Journal of Micropaleontology, 9 (1), 1-14.

Barker, R. W., 1944, Some larger Foraminifera from the Lower Cretaceous of Texas: Journal of Paleontology, 18 (2), 204-209.

Bazáñez, L.M., Fernández Turner, R., Rosales D.C., 1993, Cretaceous Platform of Valles-
San Luis Potosí, Northeast central Mexico, in Simó, J.A., Scott, R.W., Masse, J.P. (eds.), Cretaceous Carbonate Platforms: American Association of Petroleum Geologists Memoir, 56, 51-59.

Bonet, F., 1952, La facies urgoniana de Cretácico medio de la Región de Tampico: Boletín de la Asociación Mexicana de Geólogos Petroleros, 4, 153-262.

Bonet, F., 1956, Zonificación microfaunística de las Calizas Cretácicas del Este de México: Boletín de la Asociación Mexicana de Geólogos Petroleros, 8, 389-489.

Bonilla-Rodríguez, A.J., 2013, Carbon Isotope $\left(\delta^{13} \mathrm{C}\right) \quad$ Stratigraphy and Biostratigraphic record of the Mid-Cretaceous Hatillo Limestone in the Seibo Tectonic Terrane of the Dominican Republic. Southeastern Section, 62nd Annual Meeting, Geological Society of America Abstracts with Programs: 45 (2), 3.

Bonilla Rodríguez, A.J., González, L.A., Walker, D.J., Santos, H., 2014, Strontium isotope $87 \mathrm{Sr} / 86 \mathrm{Sr}$ stratigraphy of the CoalcomanaCaprinuloidea rudist assemblage in the Greater Antilles (Puerto Rico, Dominican Republic and Jamaica): Cretaceous Research, 50, 97-109.
Dagher-Fadel, M.K, 2001, The taxonomy and evolution of the foraminiferal genus Buccicrenata Loeblich and Tappan: Micropaleontology, 47 (2), 168-172.

Boudagher-Fadel, M.K., Banner, F.T., Gorbatchik, T.K., Simmons, M.D. Whittaker, J.E., 1996, Evolution in the Early Cretaceous planktonic foraminiferal genus Blefuscuiana: Jahrbuch für Geologie und Paläontologie Abhandlungen, 202, 243-258.

Bozkurt, S., 2015, Lithostratigraphy, Depositional Environment and Diagenetic History of the Lower and Upper Cretaceous Section of TEC DIWS-1 Deep Well, Polk County, Florida: Electronic Theses, Treatises and Dissertations, (Masters Thesis). Florida State University: http://purl.flvc.org/fsu/fd/ 
FSU_migr_etd-9557

Buitrón, B.E., Carrillo-Martínez, M., RosalesDomínguez, M.C., Aguilera-Franco, N., 1995, A middle Albian biota (Algae, Foraminifera and Gastropoda) from Ahuacatlán State of Queretáro, Mexico: Revista Mexicana de Ciencias Geológicas, 12 (2), 145-156.

Carsey, D.O., 1926, Foraminifera of Cretaceous of central Texas: Texas University Bulletin, 2612, 1-56.

Carrillo-Bravo, J., 1971, La Plataforma VallesSan Luis Potosí: Boletín de la Asociación Mexicana de Geólogos Petroleros, 23, 1-102. Cherchi, A., 2004, Evolution and paleogeographic distribution of Orbitolinids (Larger Foraminifera) in the Urgonian carbonates platforms of SW Europe. Comparison with Caribbean Tethyan species: Geological Society of America, Abstracts with Programs $36(4), 83$.

Cherchi, A., Schroeder, R., 1984, Reworked middle Cretaceous orbitolinid foraminifers from southwestern Gulf of Mexico (Deep Sea Drilling Project Leg 77, Site 535), in Buffler, R.T., Schlager, W., et al., Init. Reports DSDP, 77: Washington (U.S. Govt. Printing Office), 585-586.

Clavel, B., Busnardo R., Charollais J., Conrad, M.A., Granier B., 2010, Répartition biostratigraphique des orbitolinidés dans la biozonation à ammonites (plate-forme urgonienne du Sud-East de la France) Partie 1: Hauterivien supérieur-Barrémien basal: Carnets de Géologie Notebooks on Geology, Brest Article 2010/06, 1-53.

Douglass, R.C., 1960, The foraminifera genus Orbitolina in North America. Geological Survey Professional Paper, 33, 1-51.

Elliott, G.F., 1956, Further records of fossil calcareous algae from the Middle East: Micropaleontology, 2, 327-334.

Elliott, G.F., 1957, Algues calcaires codiacées fossiles d'Iraq, nouvelles et peu connues:
Bulletin de la Société Géologique de France, 6 (6), 789-795.

Enos, P., Minero, C. J., Aguayo, C.E., 1983, Sedimentation and diagenesis of midCretaceous platform margin, east central Mexico: Dallas Geological Society Guidebook, 164 p.

Enos, P., Stephens, B. P., 1993, Mid-Cretaceous basin margin carbonates, east central Mexico: Sedimentology, 40, 539-556.

Filkorn, H., Scott, R.W., 2011, Microfossils, paleoenvironments and biostratigraphy of the Mal Paso Formation (Cretaceous, upper Albian), State of Guerrero, Mexico: Revista Mexicana de Ciencias Geológicas, 28 (1), 175-191.

Flores de Dios, A., Omaña, L., Alencaster, G., 2004, Aspectos sedimentológicos y asociaciones faunísticas del Albiano medio de la Formación Morelos en Ixcateopan, Guerrero (Sur de México): IV Reunión Nacional de Ciencias de la Tierra, Libro de Resúmenes, Juriquilla, Querétaro, México, 126.

Flügel, E., 2004, Microfacies of Carbonate Rocks. Analysis, Interpretation and Application: Germany, Springer, 976 p.

Fourcade, E., Piccioni, L., Escribá, J., Rosselo, E., 1999, Cretaceous stratigraphy and paleoenvironments of the southern Petén Basin, Guatemala: Cretaceous Research, 20, 793-811.

Frizzell, D.L., 1954, Handbook of the Cretaceous foraminifera of Texas: Texas University Bureau of Economic Geology Rept. Inv. 22, $232 \mathrm{p}$.

Garfias, V.R., 1915, The oil region of northeastern Mexico: Economic Geology, 10, 195-224.

Granier, B., 2005, Reappraisal of the Cretaceous stratigraphy section of the Bahama Escarpment (off Cat Island), based on samples dredged by the DSRV Alvin. Scientific Program and Abstracts, $7^{\text {th }}$ International Symposium on the Cretaceous, Neuchâtel, 
Switzerland, September 5-9, 98-99.

Grötsch, J., Schroeder R., Sybille, N., Flügel, E., 1993, Carbonate platform as records of high amplitude eustatic sea-level fluctuations: the late Albian appenninica event: Basin Research, 5 (4), 197-212.

Huber, B.T., 2006, Mesozoic Planktonic Foraminiferal Working Group (coordinator): Mesozoic Planktonic Foraminifera Taxonomic Dictionary, www.chronos.org.

Keijzer, F.G., 1942, On a news genus of arenaceous foramnifera fronm the Cretaceous of Texas: Proceedings K Nederlandse Akademie Wetensch, 45, 1016-1017.

Konishi, K., Epis, R.C., 1962, Some Early Cretaceous calcareous algae from Cochise County, Arizona: Micropaleontology, 8 (1), 67-76.

Loeblich, A.R. Tappan, H., 1949, Foraminifera from the Walnut Formation (Lower Cretaceous) of Northern Texas and Southern Oklahoma: Journal of Paleontology, 23 (3), 245-266.

Lozo, F. T., 1944, Biostratigraphic relations of some north Texas Trinity and Fredericksburg (Comanchean) foraminifera: The American Midland Naturalist, 31(3), 513-582.

Lucas, S., Kraimer, K., Spielmann, J.A., 2010, Cretaceous stratigraphy, paleontology, petrography, depositional environments and cycle stratigraphy at Cristo Rey Doña Ana County, New Mexico: New Mexico Geology, 32 (4), 117-144.

Magniez, F. 1972, Spiroplectamminoides, nouveau genre des Foraminifères des Formations Para-Urgoniennes Cantabriques (Espagne): Revista Española de Micropaleontología, No. Extraordinario XXX Aniversario Editorial N. Adaro, 179-198.

Magniez, F., 1974, Novalesia, nouveau nom pour le genre de foraminifère Spiroplectamminoides Magniez, 1972: Revista Española de Micropaleontología, 6, 155.

Magniez-Jannin, F., 1975, Les Foraminifères de l'Albien de l'Aube: Paléontologie,
Stratigraphie, Écologie: Cahiers de Paléontologie, GNRS, 360 p.

Masse,J-P., 1992, The Lower Cretaceous Mesogean benthic ecosystems: Palaeoecological aspects and palaeobiogeographic implications: Palaeogeography, Palaeoclimatology, Palaeoecology, 91, 331-345.

Maync, W., 1955a, Dictyoconus walnutensis (Carsey, 1926) in the mid-Albian Guacharo limestone of eastern Venezuela: Contributions from the Cushman Foundation for Foraminiferal Research, 6, part 3, 85-96.

Maync, W., 1955b, Coskinolina sunnilandensis n. sp. a Lower Cretaceous (Urgonian- Albian) species: Contributions from the Cushman Foundation for Foraminiferal Research 6, part 3, 105-11.

Meyerhoff, A.A., Hatten, G. W., 1974, Bahamas salient of North America. In Burk, C.A., Drake, C.L. (eds.): The Geology of Continental Margins, Springer-Verlag New York, 429-446.

Michael, F.Y., 1972, Planktonic foraminifera from the Comanchean Series (Cretaceous) of Texas: Journal of Foraminiferal Research, 2, 200-220.

Michaud, F., 1987, Stratigraphie et paléogeographie du Mesozoique du Chiapas (Sud Est du Mexique): Académie de Paris Université Pierre et Marie Curie: Mémoires de Sciences de la Terre, 87, 298 p.

Minero, G.J., 1982, Depositional environments and porosity evolution, El Abra Limestone (Cretaceous) Mexico: The American Association of Petroleum Geologists Bulletin, 66 (5), 607.

Monreal, R., Longoria, J.F., 1999, A Revision of the Upper Jurassic and Lower Cretaceous stratigraphic nomenclature of the Chihuahua trough, north central Mexico: Implications for lithocorrelations, in Bartolini, C., Wilson, J.L., Lawton, T.F. (eds.), Geological Society of America Special Paper, 340, 69-92.

Morrow, A.L. 1934, Foraminifera and Ostracoda from the Upper Cretaceous of Kansas: 
Journal of Paleontology, 8 (2), 186-205.

Moullade, M., 1965, Contribution au problème de la classification des Orbitolinidae (Foraminiferida, Lituolacea): Comptes Rendus Hebdomadaires des Séances, 260, 4031-4033.

Muir,J.M., 1936, Geology of the Tampico Region, Mexico: Tulsa, Oklahoma, American Association of Petroleum Geologists, 280 p.

Murray, J.W., 2006, Ecology and Applications of Benthic Foraminifera. Cambridge University Press, Cambridge, 164-170.

Nigra, J.O., 1950, El Cretácico medio de México, con especial referencia a la facies de Caliza Arrecifal del Albiano-Cenomaniano en la Cenobahia de Tampico-Tuxpan: Boletín de la Asociación Mexicana de Geólogos Petroleros, 3 (3-4), 107 p.

Omaña, L., Alencáster, G., 2001, Albian community from the El Abra Formation from East-Central México. North American Paleontological Convention 2001, Paleobios, 21 number 2 supplement, Museum of Paleontology University of California, Berkeley, USA, Program \& Abstracts, 100.

Omaña, L., López Doncel, R., Torres Hernández J.R., Alencáster, G., 2013, Biostratigraphy and paleoenvironment of the Cenomanian/ Turonian boundary interval based on foraminifera from the western part of the Valles-San Luis Potosí Platform, Mexico: Micropaleontology, 58 (6), 457-485.

Ornelas, M., Franco Navarrete, S., Granados Martínez, M., Segura Treviño, A., Torres Estrada, C., Ruiz Ruiz, H., 2006, Análisis y evolución de las facies arrecifales de la Formación El Abra (Aptiano-Cenomaniano) de la Cuenca Tampico-Misantla: Memoria $\mathrm{X}$ Congreso Nacional de Paleontología. Universidad Nacional Autónoma de México. Instituto de Geología Publicación Especial 5, 123-124.

Phelps, R.M., Kerans, Ch., Da-Gama Rui, O.B.P., Jeremiah, J., Hull, D., Loucks, R., 2015,
Reponse and recovery of the Comanchean carbonate platform surrounding multiple Cretaceous OceanicEvents, northern Gulf of Mexico: Cretaceous Research, 54, 117144 .

Premoli-Silva, I., Sliter, W., 2002, Practical Manual of Cretaceous Planktonic Foraminifera. Perugia: Tipografia Pontefelcino, Universities of Milan and Perugia, International School on planktonic foraminifera, Course 10, 461 p.

Premoli-Silva, I., Verga, D., 2004, Practical Manual of Cretaceous Planktonic Foraminifera. Perugia: Tipografia Pontefelcino, Universities of Milan and Perugia, International School on planktonic foraminifera, Course 30, 283 p.

Rod, E., Maync, W., 1954, Revision of the Lower Cretaceous Stratigraphy of Venezuela: The American Association of Petroleum Geologists Bulletin, 38 (2), 193-283.

Rosales-Domínguez, M.C., 1998, Mid Cretaceous Albian foraminifera of El Madroño, State of Queretáro, central Mexico: Revista de la Sociedad Mexicana de Paleontología, 8(2), 180-185.

Salvador, A., 1991, Origin and development of the Gulf of Mexico basin, in Salvador, A. (Ed.), The Gulf of Mexico Basin: The Geology of North America, V J., p. 389-444.

Schroeder, R., Neumann, M., 1985, Les grands foraminifères du Crétacé moyen de la Région Méditerranéenne: Geobios, Mémoire Spécial, 7, 161 p., 68 pl.

Scott, R.W., 1990, Models and Stratigraphy of mid-Cretaceous reef communities, Gulf of Mexico, in Lidz, B.H. (ed.), SEPM Concepts in Sedimentology and Paleontology, 2, 1-99.

Scott, R.W., Benson, D.G., Mori, R.W., Shaffer, B.L., Oboh-Ikuenobe, F.E., 2003, Integrated Albian-lower Cenomanian chronostratigraphic standard. Trinity River Section, Texas: U.S Gulf Coast Cretaceous stratigraphy and paleoecology. Perkins 
Memorial Vol., 277-337.

Scott, R.W., Finch, R.C., 1999, Cretaceous carbonate biostratigraphy and environments in Honduras, in Mann (ed.), Caribbean Basins. Sedimentary Basins of the World, Chapter 6, Amsterdam, Elsevier Science B.V., 151-165.

Scott, R.W., González-León, G., 1991, Paleontology and biostratigraphy of Gretaceous rocks Lampazos area, Sonora, Mexico: Geological Society of America Special Paper, 254, 51-67.

Scott, R.W., González-León, C., 2004, Stratigraphy and sedimentology of the upper Aptian-upper Albian Mural Limestone (Bisbee Group) in northern Sonora, Mexico: Cretaceous Research, 25, 43-60.

Silvestri, A., 1932, Revisione di Orbitoline Nordamericane: Pontificia Accademia dei Nuovi Lincei Mem, ser. 2, vol. 16, 371-394.

Smith, B.A., 1986, Upper Cretaceous stratigraphy and the mid-Cenomanian unconformity of East-Central Mexico. Ph. D. thesis. The University of Texas at Austin, 188 p.

Suter, M., 1984, Cordilleran deformation along the eastern edge of the Valles-San Luis Potosí carbonate Platform, Sierra Madre Oriental fold thrust east-central Mexico: Geological Society of America Bulletin, 95, 1387-1397.

Suter, M., 1987, Structural transverse across the Sierra Madre Oriental fold thrust eastcentral Mexico: Geological Society of America Bulletin, 98, 249-264.

Suter,M., 1990, GeologíadelaHoja Tamazunchale, Estados de Hidalgo, Querétaro y San Luis
Potosí: Instituto de Geología, UNAM, 55p.

Tavitas, G.J., Solano, M.B., 1984, Estudio bioestratigráfico del subsuelo en el oriente de la Plataforma Valles-San Luis Potosí. Memoria del Tercer Congreso Latinoamericano de Paleontología, in Perrilliat, G. (ed.), Oaxtepec, México, 225236.

Vanderpool, H.C., 1933, Upper Trinity microfossils from southern Oklahoma: Journal of Paleontology, 7(4), 406-411.

Waite, L.E., Scott, R.W., Kerans, Ch., 2007, Middle Albian of the regional dense marker beds of the Edwards Group, Pawnee Field, south central Texas: Gulf Coast Associations of Geological Societies Transactions, 57, 759-774.

Wilson, J.L., Ward, W.C. 1993, Early Cretaceous carbonate platforms of northeast and east central Mexico, in Simó, J.A., Scott, R.W., Masse, J.P. (eds.), Cretaceous Carbonate Platforms: American Association of Petroleum Geologists Memoir, 56, 35-49.

Young, K., 1977, Middle Cretaceous rocks of Mexico and Texas: Bureau of Economic Geology. The University of Texas, Reports of Investigations, 89, 325-332.

Young, K., 1984, Biogeography and stratigraphy of selected middle Cretaceous rudists of southwestern North America. Tercer Congreso Latinoamericano de Paleontología, in Perrilliat, G. (ed.), Oaxtepec, Mexico, 341360. 